\title{
Effect of Environmental CSR Activities on the Financial Performance of Financial Institutions in Kirinyaga County.
}

\author{
Martin Kamau Muchiri \\ School of Business \& Economics, Kirinyaga University \\ Dr. Robert Gitau Muigai \\ School of Business \& Economics, Kirinyaga University
}

\begin{abstract}
:
A new dimension to the corporate world have been brought up in the recent past by the CSR practices adopted by the financial institutions across the world. Previous research seeking to find out the effect of CSR on the financial performance of various institutions have yielded different results. This study aimed at finding out the effect of Corporate Social Responsibility activities on the financial performance of Financial Institutions in Kirinyaga County. Specifically, the study aimed at determining the effect of Environmental CSR activities on the financial performance of the financial institutions in Kirinyaga County. The study was based on the stakeholder's theory. The study population was 300 employees working in the financial institutions in Kirinyaga County and a sample of 171 employees was used for the study. A causal research design was adopted while carrying out the research. The researcher used both the stratified and systematic sampling techniques to select the sample. Primary data was gathered through administration of questionnaires to the selected respondents in the financial institutions while Secondary data was sourced from journals, libraries, e-books and the websites of the financial institutions. Financial performance was assessed on the basis of the net profit after tax for the firms. The data was analysed using the SPSS version 23 software. The study found a strong positive relationship between environmental CSR practices and financial performance of financial institutions. The study recommended that financial institutions should invest in environmental CSR activities as such activities positively influence their financial performance.
\end{abstract}

Keywords: Environmental CSR activities, financial performance, financial institutions, Kirinyaga County.

DOI: $10.7176 /$ RJFA/10-5-07

Publication date:March $31^{\text {st }} 2019$

\subsection{Introduction}

Corporate social responsibility is the obligation of corporations to make decisions, formulate policies and adopt actions which are consistent with the values and desires of the society (Branco \& Rodrigues, 2006). The concept of CSR entails various environmental and social areas such as employee relationships, community welfare, human rights and ethics. Corporate Social Responsibility as a concept entails corporate practice where entities integrate voluntarily both social and environment uplift in their business operations and philosophy.

A new dimension to the corporate world has been brought up in the recent past by the CSR practices adopted by the financial institutions. Financial Institutions both in developing and developed countries are adopting various initiatives of engaging in social activities, regulatory requirements and social awareness in the recent past. The pressure from some Non-Governmental Organizations (NGOs) and other social activists have a big role in fuelling the CSR practice among financial institutions and other businesses (Okoth, 2012). Consumers nowadays want to see actions which are tangible and demonstrate that financial institutions surely hold their interests dearly. The emergence of social media has also played a major role in empowering the consumers: Consumers now have a platform to showcase what they want and demand for response from the financial institutions among other businesses. The contribution of the CSR activities is analysed as a source of competitive advantage as an end itself (Branco and Rodrigues, 2006). Businesses with a good reputation creates value of a firm through eliminating negative rumours about a firm and also through attracting additional customers thus indirectly improving the profitability of the firm. CSR practices also help in the management of the stakeholders relationships which motivate the investors to provide more capital to the business (Weber, 2008). According to Falck and Heblich (2007), CSR earns a good reputation to a firm which makes it highly attractive to human capital with high skills and expertise.

After the financial crises of 2008 , there exist evidence that financial institutions are taking the social obligation more seriously. For instance, in August 2012, the CSR annual report released by the Bank of America highlighted a set of initiatives such the $\$ 1.5$ trillion budget for promoting the community investment and lending goal; $\$ 50$ billion budget for promoting the environmental business goal, ten-year, $\$ 2$ billion budget for promoting philanthropic investment goal. In September 2012, a full CSR report was released, outlining the global efforts which the firm had to aid in strengthening the communities which it operates, the economy, promote environmental sustainability and expand the opportunities for education. 
There are 43 registered commercial banks in the Kenyan Sector, nine microfinance institutions taking customer deposits, one mortgage finance corporation, seven foreign banks representative offices, a hundred and five foreign exchange bureaus, two credit reference bureaus as at October 31, 2016. Kirinyaga County has 16 financial institutions namely Cooperative Bank, Equity bank, Family bank, Barclays Bank, Feb Bank, KCB, Sidian Bank, Bingwa Sacco, Ollin Sacco, Kirinyaga farmers Sacco, Bima Sacco, Fortune Sacco, Century bank, Nufaika Sacco and Goodway Sacco. Other financial institutions in the County include KWFT and Agriculture Finance Corporation. Financial institutions have been seen to take keen interest as observed in the last few decades on Corporate Social Responsibility. This is evident from what is seen on the firm's website and annual reports regarding CSR involvement. Most firms dedicate some pages which highlight the contributions they make at the end of the year. The Financial institutions have engaged in a series of CSR activities which includes leadership development and education, financial access and literacy, agriculture, entrepreneurship, health, environmental sustainability, innovation, humanitarian intervention, corporate governance enterprise development, community development, workplace issues and business ethics.

In Kenya, many researchers have carried out studies seeking to examine the effect of Corporate Social Responsibility on the economic and financial performance and have found mixed findings. Many studies have viewed CSR as the interaction of the organization with its social and physical environment, community involvement, customer/product safety, natural environment and disclosures relating to human resources. Conclusively, studies carried out in Kenya examining the effect of CSR and corporate financial performance have indicated four major categories of findings. Some studies have found a neutral relationship, others have found a positive relationship, and some negative and others mixed relationships. Companies operating in Kenya have been under great pressure with the rising temperatures by activists, NGOs, and the government agencies to be accountable for their actions. The government has recently banned the use of plastic bags which had posed a major threat to the environment. The success of the plastic paper ban is an indication that the members of the public are becoming even more conscious of the practices carried out by firms.

\subsection{Statement of the Problem.}

Different studies have examined the different aspects of CSR on the financial performance of firms and different results have been yielded. Orlitzky et al. (2003) in their study found a solid relationship between CSR and CFP. Studies carried out by Ngwake (2009), Hasan et al., (2011), Ponn \& OKoth (2009) and Erhemjants et al., (2011) revealed a positive relationship between CSR and Corporate Financial Performance. Nelling and Webb (2009) who assessed the relationship between CSR and Return on Assets, (ROA) concluded that there is no evidence that CSR is identified with the financial performance of a firm. Another study conducted here in Kenya by Kepkemoi (2010), also indicated that there is no relationship between CSR and ROE.

Barnett \& Salomon (2012), detected a U- shaped CSR- CFP relationship where firms which invest low in CSR has a high CFP while those which invest moderately in CSR have even lower CFP while those that invest highly in CSR has the highest CFP. Part of the works looked into by Margolis and Walsh (2003), indicate that 53 per cent of those researched indicate that a positive relationship exists between CSR and the CFP. According to Daniel (2014), the statistics indicate that majority of commercial banks in Kenya have increased their allocations for CSR activities. According to the data collected by Daniel (2014), the allocations for Equity bank from 2009 to 2013 increased respectively as follows $80,3 \mathrm{M}, 83.049 \mathrm{M}, 10.92 \mathrm{M}, 23.5 \mathrm{M}$ and $555.311 \mathrm{M}$. The CSR allocations for Cooperative bank starting from 2009 to 2013 were $70 \mathrm{M}, 87 \mathrm{M}, 85.2 \mathrm{M}, 89.6 \mathrm{M}$ and $95.54 \mathrm{M}$ respectively. The CSR allocations for KCB within the same period were $70 \mathrm{M}, 78 \mathrm{M}, 157 \mathrm{M}, 151 \mathrm{M}$ and $172 \mathrm{M}$ respectively. The statistics indicates clearly that the commitment on CSR investment by businesses has also grown rapidly.

Based on the assessed studies, it can be concluded that there lack a decisive directional association between the CSR activities of a firm and its financial performance. The empirical observations are therefore contradictory and creates a scholarly gap which needs to be investigated further. Other researchers has found no relationship between investing in CSR and the financial returns especially for small firms. The empirical literature reveals that no research have been done to assess the effect environmental CSR activities on the financial performance. This creates a dilemma to managers in making decisions regarding environmental CSR investments given the fact that the managers too need to maximize the wealth of the shareholders. The study therefore seeks to bridge the scholarly gap by finding out the effect Environmental CSR activities have on the Financial Performance of the Financial Institutions in Kirinyaga County.

\subsection{General Objective}

The major objective of this research was to establish the effect of Environmental CSR activities on the financial performance of Financial Institutions in Kirinyaga County. 


\subsection{Literature Review}

This section provides the theoretical framework as well as the empirical literature which is relevant for the study.

\subsection{Shareholder Primacy Theory}

The shareholders primacy theory proposes that the main aim of a firm is to maximize the wealth of its shareholders and the social factors should not be an interference to achieving this objective. It implies that the firm's investments in the social obligations should not be a priority however, the modern business setting requires firms to adopt a more proactive approach to CSR investments in order to mitigate the associated social risks. The firm's reputation and perception from the customer's end matters much in helping a firm achieve the profit maximization motive. Risk management through the implementation of strategies which are socially responsible and community engagement is linked to stakeholder's confidence and business success.

According to Carroll \& Shabana (2010), the existence of important intangibles such as trust, a good corporate culture, ethics, environmental behaviour and customer satisfaction is becoming even more relevant to business stakeholders such as business partners, employees, investors, government, special interest groups and consumers. The worldwide market has unleashed a vast amount of innovations in the last two hundred years. Carroll \& Shabana (2010), insists that environmental responsibility is becoming more relevant to business stakeholders.

According to Visser et al., (2010), people have become blind of their actions which are harmful to others and environment. Such actions are summarised as inequitable distributions of opportunities, environmental degradation and the dominance of the groups which are les privileged. These are the troubling issues. According to Kotler \& Lee, (2011), the fruits of these issues are already germinating. Challenges such as global terror attacks, financial crisis and global warming have become major threats to the stability of the world. It is more imperative than ever for scholars to study how responsible behaviour can be encouraged and institutionalized. The stakeholder's supremacy theory articulations is a major evidence of the need for scholars to adopt a more morally rich way of thinking given the modern business setting. The theory is connected to the Corporate Social Responsibility in the sense that it advocates for a consideration of shareholders wealth. The theory however overlooks the interest of the other stakeholders as it advocates that social and environmental factors should not interfere with the goal of wealth maximization for the shareholders. The implication of the theory is that firms should invest less in addressing the social and environmental needs of the society due to the social costs involved. The dynamisms in the business environment however may disadvantage a firm which only addresses the needs of the shareholders alone. This study aimed at determining whether investing in the Environmental CSR activities have any effect on the financial performance of a firm. The findings of the study thus were inconsistent with the contentions of the theory.

\subsection{Review of variables}

\subsubsection{Environmental Activities}

Corporate Social responsibility is a concept where firms are required to integrate the environmental and social concerns in their interactions with various stakeholders as well as business operations without coercion (European Commission, 2006). There is limited understanding of what exactly CSR is due to the absence of a clear consensual definition of the concept. Weber (2008) says that there lacks a universally accepted definition of what CSR and mentions that it is yet to emerge. Amaeshi and Adi (2005), describes the CSR as vague, ambiguous, fuzzy, amorphous and subjective. Khanifar et al., (2012), defines CSR s that responsibility charged to the community and the stakeholders of influencing practices and policies which promote the interests of the society and the environment.

According to Gilbert (2008), CSR initiatives are dependent of the institution environments in which the companies operate. The surroundings in which a firm is established confines the firm to behave responsibly in a bid to address the challenges affecting the environment. For instance, every financial institution such as a bank, deposit Sacco or any other firm needs to retain its customers to that it can remain relevant in the industry and compete favourably. Such an environment forces the firms to be responsible as that is one of the aspects of retaining the customers.

The findings of a study carried out by Klassen and Mc Laughlin (1996), indicated that the management of the environment significantly matters in influencing the performance of a firm. The conclusion of the study were that there exist a significant relationship between organizational performance and environmental management. In another study conducted by Li X (2009) in China seeking to assess the index system of various corporations found that those corporations with high index scores also recorded high financial performance. Anyona (2005), also found a positive relationship between portfolio performance and CSR. He also attributed the good performance to the good corporate image created by the company through engaging into responsible environmental activities and ethical activities. He noted that investors prefer companies which have a good corporate image. 
According to Mobil (2012), Corporate Social Responsibility is a commitment by corporations to consider the interests of all the stakeholders who are influenced by its activities but not only its shareholders. Mobil (2012), specifically focused on the implication of environmental CSR. Connelly (2011), adds that the CSR commitments in light of environmental CSR by businesses is a holistic approach and goes beyond the financial bottom line. According to Birmingham (2011), the global movements against environmental depletion has pointed out the threat of long term business prosperity and has recommended a change on the existing business practices to a more CSR focused approach. Birmingham (2011) notes that the current industries have tolerated a carbon economy where ecologically unfriendly practices are tolerated at cost. Clark \& Master (2012) argues that businesses can implement the CSR activities even without the coercion by the government. Birmingham (2011) argues that if businesses embrace environmental friendly practices, then it would be possible to thwart the exhaustion of renewable resources.

\subsection{Empirical Literature}

There have been many studies conducted locally and globally and the findings are inconclusive and mixed. A study was conducted by Abiodun (2012) in Nigeria seeking to find out the relationship between CSR and the profitability of a firm. The study involved collection of secondary data from ten profitable firms in the country. The firms were all listed in the Nigerian Stock Exchange and were selected randomly. The study used a regression analysis and found a negative relationship between CSR and profitability. Ngwakwe (2009) conducted a research in Nigeria seeking to determine the relationship between environmental sustainability and the firm's performance. The study utilized sixty companies from the manufacturing sector. The findings were that there existed a direct relationship between sustainable practices and the firm's performance.

In another study, Hasan et al., (2011), also conducted a study in Bangladesh to determine the relationship between CSR and Financial performance. The study involved a comparison of 5 selected banks which were considered socially responsible with 12 other banks which were not socially responsible. The findings of the study indicated better performance for the socially responsible banks though the difference was statistically insignificant. Another study was conducted by Tsoutsoura (2004) and aimed at determining the relationship between CSR and CFP. The study utilized 422 firms and involved data of the last 5 years. The study found a significant and a positive relationship between CSR and CFP.

In a study conducted by Marcia, Otgontsetseg and Hassan (2013), seeking to find out whether commercial banks in the United States have invested in CSR and if the firms also receive rewards for their actions. The study utilized the CSR data that was available publicly for the analysis. They found that the large banks which yield high profits, charger low fees on the customers and have high capital ratios had high CSR strengths. The study found out that the large banks were highly rewarded by their social actions as there was a significant positive relationship between ROA, ROE and CSR scores. The high participation in CSR by the banks resulted to high financial performance. The study revealed that there was an alignment of the strategic intent with the CSR programs and the CSR efforts meet with the expectations of the investors, local communities and employees.

Ongolo (2012) carried out a research in Kisumu county seeking to investigate whether there is a relationship between Corporate Social Responsibility and the market shares of the supermarkets in the city for the period between 2006 and 2010. The study found a strong relationship between CSR and the market share of the supermarkets. The institutions which had invested highly in the CSR also earned high revenues. The study also revealed a positive correlation coefficient between CSR and the market share index. The large supermarkets preferred water and sanitation and education while others preferred to undertake their CSR activities through supporting the less fortunate in the society.

Okoth (2012), in his study on the effect of CSR on CFP found that the financial performance of the large and medium sized banks was good while there was no effect on the ROA of the small banks. Mutuku (2004) also found similar results. In aggregate, the researcher found a positive relationship between CSR and financial performance however, regarding the market size, there was insignificant relationship between CSR and the smaller banks. The researcher concluded that engaging in CSR was not in the interest of the shareholders for the small banks as such investments would only drain their wealth without yielding any return to the institutions.

Margolis, Elfenbein and Walsh (2007), in their meta-analysis involving 167 studies found out that 58\% indicated a non-significant relationship, $27 \%$ indicated a positive relationship while $2 \%$ indicated a negative relationship between CFP and CSR. The researchers concluded that the CSR is considered as a valuable resource. In an effort to support this finding, the researchers found that the firms which adopted the proposals which were shareholders related also recorded superior financial performance. The study found that the firms gained an increase of $0.7 \%$ to $0.8 \%$ in their ROA within two fiscal years following the adoption of the CSR activities.

Okiro, Omoro and Kinyua (2013), also conducted a study seeking to find out the relationship between CSR investments made and their impact on the sustained growth of the banks. They found that CSR investments contributed to the banks growth.

In Kenya, most many studies have been conducted on CSR though not necessarily seeking to find out the 
effect of Environmental CSR activities on the financial performance of firms.

\subsection{Research Gap}

This research sought to bridge two main gaps. The empirical literature revealed a geographical gap for the study. The study have not been conducted in Kirinyaga County. The literature also revealed a sector gap as there are no studies conducted in small financial institutions and microfinance institutions. This study therefore sought to bridge the geographical and sector gap.

\subsection{Research Methodology}

This section explains the research design and methodology that the study seeks to employ

The study used a causal research deign. Descriptive statistics were used to explain the results of the study. Descriptive statistics were used to explain the results of the study. According to Njiru (2013), descriptive statistics helps the researcher to summarize the quantitative data using the mean score and the standard deviation. The causal research design assisted the researcher to make comprehensive findings on the subject matter. The total target population was the 300 employees working in the 16 financial institutions operating in Kirinyaga County (Kirinyaga county government, 2018). While deciding the size of the sample, the study used the Yomane Formulae which assumes a 95\% confidence level (Israel, 1992) and a sample size of 171 employees was used for the study. The population was organized into strata as employees came from different financial institutions. The target population was stratified into commercial banks, Saccos, microfinance institutions and others. Systematic sampling was used to select the employees from the different strata. Questionnaires were issued to the selected employees of the financial institutions. Primary data was collected using questionnaires which were administered to the respondents. To ensure validity of the research tools, the researcher conducted a pilot study. The pilot study involved issuing 15 questionnaires for pilot test.

\subsection{Operational Definition of variables}

\begin{tabular}{lcl}
\hline Variables & The variables were be measured using the following items: \\
\hline Environmental activities & - & Existence of environmental CSR policy. \\
& - Budgetary allocations for Environmental CSR. \\
& - Establishment of garbage collection bins. \\
Financial performance & - Town clean-up initiatives. \\
& - Water conservation and sanitation activities \\
& & The financial performance of the firms was measured \\
&
\end{tabular}

\subsection{Data Analysis}

Gliner \& (2009) defines data analysis as assigning meaning to collected data. The data was analysed using SPSS version 20.0. The data was broken down into manageable units. The researcher endeavoured to synthesize the data to identify the patterns, identify what need to be learnt and make a decision on what was to be reported. Descriptive research design and a correlational researcher design were used as they are easy to compute and interpret. The data was coded and keyed in the SPSS analysis software so that the researcher would analyse and present the findings in a comparable format. Data was also presented using the tables. The responses were categorized into themes from the structured questions and further analysis was done on the same basing on the weight to frequency of relatedness and appearances.

The researcher used Karl Pearson correlation coefficients to determine the nature of relationship between employee performance and employee welfare programs. The study also conducted a linear regression analysis to determine the relationship between the Environmental CSR activities and financial performance.

The following model was used:

$\mathrm{FP}=\alpha+\beta 1 \mathrm{X} 1+\varepsilon$

Where:

$\mathrm{a}=$ Constant

$\mathrm{FP}=$ Financial performance of Financial Institutions

$\mathrm{X} 1=$ Environmental activities

$\varepsilon=$ Stochastic disturbance error term

\subsection{Results and Discussion}

The main aim of the study was to determine the effect of Environmental CSR on the financial performance of financial institutions in Kirinyaga County. This chapter presents the results of data analysis as well as the discussion of key findings of the research basing on the specific objective which was environmental activities. 
Regression and correlation findings were used to show the relationship between the variables and answer the research question.

\subsection{Descriptive Analysis}

Environmental activities by the firms were measured in terms of the budgetary allocations made on environmental CSR, participation of the financial institutions in establishing the garbage bins, participation in the city clean-up activities, participation in water sanitation activities and the existence of environmental policy. The descriptive results revealed that the respondents agreed that their financial institutions set budgetary allocations for Environmental CSR (mean, 1.54). As indicated in table 4.1, 42.1\% of the respondents strongly agreed that their firms make budgetary allocations for environmental CSR while $49.7 \%$ agreed. Collectively 91.8\% agreed that their firms makes budgetary allocations for CSR activities. $8.2 \%$ did not respond to the question. In regard to participation in the establishment of garbage bins, $11.1 \%$ strongly agreed, $22.8 \%$ agreed, $2.3 \%$ were undecided, $35.7 \%$ disagreed. $19.9 \%$ strongly disagreed while $8.2 \%$ did not respond to the question. $33.9 \%$ agreed that their institutions participate in the establishment of garbage bins while $55.6 \%$ of the respondents disagreed. The results also revealed that majority of the firms have an existing CSR policy as indicated by the mean of $1.68 .39 .2 \%$ of the respondents strongly agreed on the existence of environmental CSR policy, $44.4 \%$ agreed, $5.8 \%$ were undecided, $1.2 \%$ disagreed, $0.6 \%$ strongly disagreed while $8.8 \%$ did not respond to the questionnaire. In regard to participation of firms in city clean-up activities, $27.5 \%$ of the respondents strongly agreed that their firms participates in city clean-up activities, 40.4\% agreed, 5.8\% were undecided, $13.5 \%$ disagreed, and $4.1 \%$ strongly disagreed while $8.8 \%$ of the respondents did not respond to this question. On average $67.9 \%$ agreed that their firms participated in city clean-up activities while $17.9 \%$ disagreed that their firms participated in city clean-up activities. In average, majority of the respondents agreed that their firms participates in the city clean-up activities as indicated by the mean of 2.19. The descriptive results for participation of firms in encouraging water conservation initiatives indicates that $29.8 \%$ strongly agreed that their financial institutions is involved in promoting water conservation activities, $36.3 \%$ agreed, $3.5 \%$ were neutral, $15.2 \%$ disagreed, $6.4 \%$ strongly disagreed while $8.8 \%$ did not respond to this question. Generally, $66.1 \%$ of the respondents agreed that their firms participates in promoting water conservation activities as indicated by the mean of 2.38 in table 4.1. 21.6\% disagreed that their firms participates in city clean-up activities. In regard to descriptive statistics on the existence of an environmental CSR policy by the firms, $83.6 \%$ agreed while about $1.8 \%$ disagreed that their firms have an existing Environmental policy. On average, majority of the respondents agreed that their financial institutions participates in establishing the garbage bins as indicated by the mean (1.37). The results also revealed a high standard deviation of $0.5,1.375,1.153,1.269$ and 0.709 respectively for budgetary allocations for environmental CSR, establishment of garbage bins, participation in city clean-up activities, participation in water conservation activities and existence of an environmental CSR policy respectively. The high standard deviations for establishment in garbage bins, city clean-up activities and water conservation activities $(1.375,1.153$ and 1.269) were as a result of the high diversity of environmental activities different financial institutions choose to engage in. The results can be presented in table 4.3 as shown below. 
Table 4.1: Descriptive statistics of environmental activities

\begin{tabular}{|c|c|c|c|c|c|c|c|}
\hline Statements & $\begin{array}{l}\text { Strongly } \\
\text { agree } \\
(\%) \\
\end{array}$ & (\%) & $\begin{array}{l}\text { Neutral } \\
(\%) \\
\end{array}$ & $\begin{array}{l}\text { Disagree } \\
(\%) \\
\end{array}$ & $\begin{array}{l}\text { Strongly } \\
\text { disagree } \\
(\%) \\
\end{array}$ & Mean & $\begin{array}{l}\text { Standard } \\
\text { deviation }\end{array}$ \\
\hline $\begin{array}{l}\text { My firm has made been } \\
\text { making budgetary } \\
\text { allocations for } \\
\text { Environmental CSR }\end{array}$ & 42.1 & 49.7 & 0 & 0 & 0 & 1.54 & 0.500 \\
\hline $\begin{array}{l}\text { My firm participates in } \\
\text { the establishment of } \\
\text { garbage bins }\end{array}$ & 11.1 & 22.8 & 2.3 & 35.7 & 19.9 & 3.33 & 1.375 \\
\hline $\begin{array}{l}\text { My firm has engaged in } \\
\text { city clean-up activities }\end{array}$ & 27.5 & 40.4 & 5.8 & 13.5 & 4.1 & 2.19 & 1.153 \\
\hline $\begin{array}{l}\text { My firm engages in } \\
\text { water conservation } \\
\text { activities }\end{array}$ & 29.8 & 36.3 & 3.5 & 15.2 & 6.4 & 2.26 & 1.269 \\
\hline $\begin{array}{l}\text { My firm has an existing } \\
\text { policy on } \\
\text { Environmental CSR }\end{array}$ & 39.2 & 44.4 & 5.8 & 1.2 & 0.6 & 1.68 & 0.709 \\
\hline
\end{tabular}

\subsection{Correlational Findings}

Correlation is a statistical tool which provides the measure of the association between variables. According to Cohen, West, \& Aiken (2014), correlation also tries to explain the characteristics of the variables as well as their predictive characteristics. Karl Pearson coefficients were used to test for correlation (r) between the variables. The correlation coefficients ranges from -1 to +1 . Zero represents no association between the variables. A coefficient of -1 represents a negative relationship while a coefficient of +1 represents a positive relationship between the variables while Zero indicates no linear association between the variables. The correlational results of the study indicated that there was a weak positive relationship between financial performance and Environmental CSR activities as indicated in the table $(\mathrm{r}=0.377)$ as indicated by the table below.

Table 4.2: Correlation findings

\begin{tabular}{llll}
\hline & & $\begin{array}{l}\text { Financial performance } \\
\text { of the financial } \\
\text { institutions }\end{array}$ & $\begin{array}{l}\text { Environment } \\
\text { al CSR } \\
\text { activities }\end{array}$ \\
\hline $\begin{array}{l}\text { Financial performance of the financial } \\
\text { institutions }\end{array}$ & $\begin{array}{l}\text { Pearson Correlation } \\
\text { Sig. (2-tailed) }\end{array}$ & 1 & $.377^{* *}$ \\
& $\mathrm{~N}$ & 157 & .000 \\
Environmental CSR activities & Pearson Correlation & $.377^{* *}$ & 157 \\
& Sig. (2-tailed) & .000 & 1 \\
& $\mathrm{~N}$ & 157 & 157 \\
\hline
\end{tabular}

\subsection{Regression Findings}

To provide more insight on the relationship that exists between Environmental CSR activities and financial performance, a regression analysis was run. The results revealed that there is a weak positive relationship between the Environmental CSR activities and the financial performance as indicated by $r=0.377$. The regression coefficient $\left(\mathrm{r}^{2}\right)$ revealed that environmental activities explained about $14.2 \%$ of the financial performance of the financial institutions in Kirinyaga County. $85.8 \%$ of the financial performance can be explained by other factors other than the environmental activities. 
Table 4.3: Environmental activities and financial performance

\begin{tabular}{llllll}
\hline \multicolumn{5}{c}{ Model Summary } \\
\hline Model & $\mathrm{R}$ & R Square & Adjusted R Square & Std. Error of the Estimate & Durbin-Watson \\
\hline 1 & $.377^{\mathrm{a}}$ & .142 & .137 & .875 & 1.673 \\
\hline
\end{tabular}

a. Predictors: (Constant), Environmental CSR activities

b. Dependent Variable: Financial performance of the financial institutions

The F- test revealed that $(\mathrm{F}=1,155=25.693)$ and $\mathrm{p}=0.000$ the model was significant at a confidence level of $95 \%$ as indicated in the ANOVA table 4.11.

Table 4.4: ANOVA analysis on Environmental activities and financial performance

\begin{tabular}{|c|c|c|c|c|c|c|}
\hline \multicolumn{7}{|c|}{ ANOVA $^{a}$} \\
\hline Model & & Sum of Squares & $\mathrm{df}$ & Mean Square & $\mathrm{F}$ & Sig. \\
\hline 1 & Regression & 19.655 & 1 & 19.655 & 25.693 & $.000^{\mathrm{b}}$ \\
\hline & Residual & 118.574 & 155 & .765 & & \\
\hline & Total & 138.229 & 156 & & & \\
\hline
\end{tabular}

a. Dependent Variable: Financial performance of the financial institutions

b. Predictors: (Constant), Environmental CSR activities

The coefficient for the regression model can be presented as follows:

\section{Table 4.5: Coefficients for linear regression}

\begin{tabular}{|c|c|c|c|c|c|c|}
\hline \multicolumn{7}{|c|}{ Coefficients } \\
\hline \multirow[b]{2}{*}{ Model } & & \multicolumn{2}{|c|}{ Unstandardized Coefficients } & \multicolumn{3}{|l|}{$\begin{array}{l}\text { Standardized } \\
\text { Coefficients }\end{array}$} \\
\hline & & $\mathrm{B}$ & Std. Error & Beta & $\mathrm{t}$ & Sig. \\
\hline \multirow[t]{2}{*}{1} & (Constant) & -.441 & .284 & & -1.552 & .123 \\
\hline & $\begin{array}{l}\text { Environmental CSR } \\
\text { activities }\end{array}$ & .223 & .093 & .118 & 2.387 & .018 \\
\hline
\end{tabular}

a. Dependent Variable: Financial performance of the financial institutions

The multi-regression equation can be derived as follows:

$\mathrm{FP}=-0.441+0.223 \mathrm{X}_{1}+0.284$

\subsection{Discussion of the findings}

The findings revealed that environmental activities are positively related to the financial performance of the financial institutions $(r=0.377)$ and the relationship is significant $(\mathrm{p}=0.000)$. The correlation findings indicated that environmental activities contributes $14.2 \%$ of the changes in the financial performance. The findings of this study agree with those of

Klassen and Mc Laughlin (1996), who concluded that there exist a significant relationship between organizational performance and environmental management. Klassen and Mc Laughlin (1996) indicated that the management of the environment significantly matters in influencing the performance of a firm.

The findings are also consistent with those of Anyona (2005) who also found a positive relationship between portfolio performance and CSR. He also attributed the good performance to the good corporate image created by the company through engaging into responsible environmental activities and ethical activities noting that investors prefer companies which have a good corporate image. Financial institutions like other businesses strive to maintain their customers without losing some of them. Modern customers are more conscious of their activities carried out by the firms. Firms which demonstrate their will and commitment to participate in solving some of the social problems that come as a result of environmental degradation are able to retain their customers and attract investors who prefer firms with a well-established corporate image. Majority of the financial institutions under study were found to have an existing Environmental policy which guided their environmental activities. The results revealed that Environmental CSR activities were significant $(\mathrm{t}=-2.387, \mathrm{p}=.018)$ in influencing the financial performance of the financial institutions.

\subsection{Summary, Conclusion and Recommendations}

The main purpose of the study was to determine the effect of environmental CSR activities on the financial performance of financial institutions in Kirinyaga County. Specifically, the study aimed at determining whether environmental CSR activities have an effect on the financial performance of the financial institutions under study. The regression findings revealed that environmental and ethical CSR activities are positively related to the financial performance of the financial institutions in Kirinyaga County. The results revealed a significant positive relationship between environmental activities and financial performance. The CSR practices included in this study were found to be significant determinants of financial performance. The findings of the study agreed with the results of many other scholars. 
The findings of the study revealed that environmental activities positively affect the financial performance of the financial institutions and the relationship is significant. The study concluded that the identified environmental CSR activities affects the performance of financial institutions. The results were however inconsistent with a few researchers who found no relationship between environmental CSR and the financial performance while others found a U-shaped relationship between CSR and Financial performance.

Based on the findings above, the study makes the following recommendations:

First, the findings revealed that environmental CSR activities are positively related to the financial performance. The study therefore recommends that financial institutions should make budgetary allocations to promote the environmental activities as such investments leads to financial gain in the long run.

\section{References}

Abiodun, B.Y. (2012). The Effect of Corporate Social Responsibility on Firms Profitability in Nigeria. European Journal of Economics, Finance and Administrative Age. American Economic Review, 62, 134139.

Ahmed, W., Mahmoud, K. A. \& Arkan,W.A. (2014). Does corporate social responsibility lead to improve firm financial performance? Evidence of Malaysia .International Journal of Economics and Finance, 6 (3), 126135.

Anyona, E. N. (2005). Social responsibility and performance of commercial banks in Kenya. Unpublished MBA project, School of Business, University of Nairobi.

Birmingham, K. (2011). Beyond the business case for corporate sustainability. Business Strategy and the Environment Journal, 11, 130-141.

Branco, M. C., \& Rodrigues, L. L. (2006). Corporate social responsibility and resource-based perspectives. Journal of business Ethics, 69(2), 111-132.

Carroll, A. B., \& Shabana, K. M. (2010). The business case for corporate social responsibility: A review of concepts, research and practice. International journal of management reviews, 12(1), 85-105.

Clark, L., \& Master, D. (2012). Corporate ESG/sustainability/responsibility reporting: does it matter. Governance \& Accountability Institute, New York.

Cohan, P. S. (2001). Net profit: how to invest and compete in the real world of internet business. John Wiley \& Sons, Inc.

Cohen, P., West, S. G., \& Aiken, L. S. (2014). Applied multiple regression/correlation analysis for the behavioral sciences. Psychology Press.

Cooper, D. R., Schindler, P. S., \& Sun, J. (2006). Business research methods (Vol. 9). New York: McGraw-Hill Irwin.

Cornett, M. M., Erhemjamts, O., \& Tehranian, H. (2014). Corporate social responsibility and its impact on financial performance: Investigation of US commercial banks. Unpublished manuscript.

Cyert, R. M., \& March, J. G. (1963). A behavioral theory of the firm. Englewood Cliffs, NJ, 2, 169-187.

Daniel, K. (2014). The Effect of Corporate Social Responsibility on Financial Performance of Commercial Banks in Kenya. Unpublished Master's Thesis: University of Nairobi.

Erhemjamts, O., Li, Q., \& Venkateswaran, A. (2011). Corporate Social Responsibility, Firm Policies, and Performance. JEL Classification: G34, M14, L21, L25, J33, M52.

Israel, G. D. (1992). Determining sample size.

Kotler,p.,\& lee, N. (2011b).corporate social responsibility: Doing the most Good for your company and your cause. John Willy \& Sons.

Margolis, J. D., Elfenbein, H. A. \& Walsh, J. P. (2007). Does it pay to be good? A metaanalysis and redirection of research on the relationship between corporate social and financial performance. Working paper, Harvard Business School, Cambridge.

Mobil K. (2012), Scoring corporate environmental and sustainability reports using GRI 2000, ISO 14031 and other criteria. Corporate Social Responsibility and Environmental Management (4): 215-233.

Mutuku, K. (2004). The Relationship between Corporate Social Responsibility and Financial Nairobi: Pauline's publications Africa.

Neville, B. A., Bell, S. J., \& Mengüç, B. (2005). Corporate reputation, stakeholders and the social performancefinancial performance relationship. European. Journal of Marketing, 39(9/10), 1184-1198.

Ngwakwe, C. C. (2009). Environmental responsibility and firm performance: evidence from Nigeria. International Journal of Humanities and Social Sciences, 3(2), 97-103.

Okoth, D. O. (2012). The Effect of Corporate Social Responsibility on the Financial Performance of Commercial Banks in Kenya. An unpublished MBA Research

Ong'olo, P. B. (2012). Relationship between Corporate Social Responsibility Practices and Market Share among Supermarkets in Kisumu Town. An unpublished MBA Research project, University of Nairobi.

Orlitzky, M. (2003). Does firm size confound the relationship between corporate social performance and firm 
financial performance? Journal of Business Ethics, 33, performance link. Strategic Management Journal, 18 (4), 303-319. Perspective. Academy of Management Review, 26 (1), 117-127.

Orlitzky, M., Schmidt, F. L., \& Rynes, S. L. (2003). Corporate social and financial performance: A metaanalysis. Organization studies, 24(3), 403-441.

Weber, (2008). Corporate social responsibility. Journal of business Ethics, 54(4), 323-337.

Wood, D. J. \& Lodgson, J. M. (2002). Business citizenship: From individuals to organizations. Business Ethics Quarterly, Ruffin Series, 3, 59-94 